\title{
Tissue Magnesium Status in Diabetes Mellitus
}

\author{
G. E. Levin, ${ }^{1}$ H. M. Mather ${ }^{2}$ and T. R. E. Pilkington ${ }^{2}$ \\ Departments of ${ }^{1}$ Chemical Pathology and ${ }^{2}$ Medicine, St. George's Hospital Medical School, London, UK
}

Summary. Leucocyte and erythrocyte magnesium was assayed in 17 healthy subjects and 17 insulin dependent diabetic patients. Plasma magnesium concentration (mean \pm standard error of mean) was significantly lower in the diabetic patients $(0.80 \pm 0.02$ $\mathrm{mmol} / \mathrm{l})$, compared with the healthy subjects $(0.90 \pm$ $0.02 \mathrm{mmol} / 1, p<0.001$ ), but the leucocyte and erythrocyte magnesium content was not significantly different in the diabetic patients $(34.5 \pm 0.8$ and $6.2 \pm$ $0.2 \mathrm{mmol} / \mathrm{kg}$ dry solids) compared with the healthy subjects $(35.5 \pm 0.8$ and $6.5 \pm 0.11 \mathrm{mmol} / \mathrm{kg}$ dry solids). In a separate study skeletal muscle obtained by needle biopsy was also assayed. Plasma magnesium in 10 diabetic patients $(0.74 \pm 0.01 \mathrm{mmol} / \mathrm{l})$ was significantly lower than in 16 healthy subjects $(0.85 \pm 0.02 \mathrm{mmol} / 1, p<0.001)$, but there was no significant difference in the mean muscle magnesium content $(43.0 \pm 0.7$ compared with $40.7 \pm 0.9$ $\mathrm{mmol} / \mathrm{kg}$ dry solids in the diabetic patients).

Key words: Magnesium, plasma, leucocytes, erythrocytes, skeletal muscle, diabetes mellitus

Hypomagnesaemia was until recently, a poorly recognised feature of diabetes mellitus $[11,20]$, but in a large survey was found to occur in about $25 \%$ of unselected diabetic outpatients [15]. Its origins are not known but it is associated with poor diabetic control [15]. It has been reported [16] that patients with severe diabetic retinopathy have a lower mean serum $\mathrm{Mg}$ concentration than those with minor changes or normal fundi, and suggested that hypomagnesaemia is a factor predisposing to the development and severity of diabetic retinopathy [16]. There is evidence also that $\mathrm{Mg}$ may be implicated in the pathogenesis and prognosis of ischaemic heart disease in nondiabetic subjects [19].
In order to investigate further the hypomagnesaemia in diabetes, tissue and plasma magnesium levels were measured as hypomagnesaemia is not necessarily accompanied by a decrease in cellular $\mathrm{Mg}$ stores [21]. The tissues analysed were leucocytes, erythrocytes, and skeletal muscle.

\section{Patients}

The first study involved 17 insulin-dependent diabetic patients. There were eight males and nine females, with ages ranging from 13 to 69 years. Reference values for plasma, leucocyte and erythrocyte electrolytes were obtained from 17 hospital personnel (12 males and five females) aged between 21 and 57 years. In the second study, ten insulin-dependent diabetic patients were selected who were found to have a plasma $\mathrm{Mg}$ below $0.74 \mathrm{mmol} / \mathrm{l}$ at a previous outpatient attendance. There were five males and five females aged between 22 and 54 years. Reference values for plasma and skeletal muscle electrolytes were obtained from 11 healthy non-diabetic patients undergoing minor surgery under general anaesthesia and from five healthy volunteers under local anaesthesia. There were ten males and six females, with ages ranging from 24 to 55 years. None of the diabetic patients or healthy subjects were receiving diuretic therapy and none had significant renal impairment as assessed by plasma creatinine or plasma urea concentration. No assessinent of retinal disease was made in the diabetic patients. Two diabetic patients in the second study were receiving thyroxine but were euthyroid, and a third was taking an oral contraceptive agent. The mean insulin dose for the diabetic patients was 58 units/day (range: $24-110$ units/day). Glycosylated haemoglobin was measured [22] in eight of the ten patients in the second study and gave a mean value of $12 \%$ (range: 10.1 to $14.7 \%$, normal range: $6-9 \%$ ).

All diabetic patients and healthy subjects gave their informed consent to the muscle biopsy and venepuncture. The study was approved by the St. George's Hospital Ethical Committee.

\section{Methods}

Venous blood samples were obtained without venestasis. In the second study, blood was collected immediately before the muscle biopsy. Plasma Mg concentration was estimated by atomic absorp- 
Table 1a. Results of plasma and leucocyte analyses in diabetic and healthy subjects

\begin{tabular}{|c|c|c|c|c|c|c|c|c|c|c|}
\hline & & \multicolumn{4}{|l|}{ Plasma } & \multicolumn{5}{|c|}{ Leucocytes } \\
\hline & & $\mathrm{Mg}$ & $\mathrm{Na}$ & $\mathrm{K}$ & $\mathrm{Ca}$ & $\mathrm{Mg}$ & $\mathrm{K}$ & $\mathrm{Mg}$ & $\mathrm{K}$ & \multirow{2}{*}{$\begin{array}{l}\text { Water content } \\
\text { (1/kg dry solids }\end{array}$} \\
\hline & & \multicolumn{4}{|c|}{$(\mathrm{mmol} / \mathrm{l})$} & \multicolumn{2}{|c|}{$\left(\mathrm{mmol} / 1\right.$ cell $\left.\mathrm{H}_{2} \mathrm{O}\right)$} & \multicolumn{2}{|c|}{$\mathrm{mmol} / \mathrm{kg}$ dry solids) } & \\
\hline & $n$ & 17 & 17 & 17 & 17 & 17 & 14 & 17 & 14 & 16 \\
\hline Diabetic & Mean & 0.80 & 144 & 4.2 & 2.48 & 13.0 & 169 & 34.5 & 451 & 2.67 \\
\hline patients & SEM & 0.02 & 1 & 0.1 & 0.04 & 0.3 & 2 & 0.8 & 5.0 & 0.03 \\
\hline \multirow{3}{*}{$\begin{array}{l}\text { Healthy } \\
\text { subjects } \\
n=17\end{array}$} & Mean & 0.90 & 142 & 4.2 & 2.47 & 13.5 & 165 & 35.5 & 435 & 2.65 \\
\hline & SEM & 0.02 & 1 & 0.1 & 0.04 & 0.4 & 2 & 0.8 & 7.0 & 0.05 \\
\hline & $p^{\mathrm{a}}$ & $<0.001$ & NS & NS & NS & $\mathrm{NS}$ & NS & NS & NS & NS \\
\hline
\end{tabular}

a The significance of difference between the means was assessed by Student's t test

$n=$ number of subjects or patients

Table 1 b. Results of erythrocyte analyses in diabetic and healthy subjects

\begin{tabular}{|c|c|c|c|c|c|c|c|}
\hline & \multicolumn{7}{|c|}{ Erythrocytes } \\
\hline & & \multirow{2}{*}{$\begin{array}{l}\text { Water content } \\
(1 / \mathrm{kg} \text { dry solids })\end{array}$} & $\mathrm{Mg}$ & $\mathrm{Na}$ & $\mathrm{K}$ & $\mathrm{Mg}$ & $\mathrm{K}$ \\
\hline & & & \multicolumn{3}{|c|}{$\left(\mathrm{mmol} / \mathrm{l}\right.$ cell $\mathrm{H}_{2} \mathrm{O}$ ) } & \multicolumn{2}{|c|}{ (mmol $/ \mathrm{kg}$ dry solids) } \\
\hline Diabetic & Mean & 1.87 & 3.3 & 11.8 & 137 & 6.2 & 257 \\
\hline $\begin{array}{l}\text { patients } \\
n=17\end{array}$ & SEM & 0.02 & 0.1 & 0.6 & 1 & 0.2 & 5 \\
\hline \multirow{3}{*}{$\begin{array}{l}\text { Healthy } \\
\text { subjects } \\
n=17\end{array}$} & Mean & 1.79 & 3.6 & 13.3 & 145 & 6.5 & 258 \\
\hline & SEM & .0 .02 & 0.1 & 0.8 & 1 & 0.1 & 3 \\
\hline & $p^{\mathrm{a}}$ & $<0.001$ & $<0.001$ & NS & $<0.001$ & NS & NS \\
\hline
\end{tabular}

a The significance of difference between the means was assessed by Student's t test

$n=$ number of subjects or patients

tion spectrophotometry (Pye Unicam SP 2900). The coefficient of variation for this assay was $2.5 \%$. Assays of plasma sodium, potassium, urea and albumin followed standard Technicon autoanalyser methods. Leucocytes were isolated by the method of Baron and Ahmed [5] with the modification that the leucocytes were resuspended in the subject's plasma for $30 \mathrm{~min}$ at $37^{\circ} \mathrm{C}$ [13]. Samples were analysed in duplicate, and the coefficient of variation of the leucocyte magnesium concentration was $6.1 \%$. Erythrocyte analysis was performed on heparinised venous blood to which had been added a trace amount of ${ }^{125}$ I-human serum albumin [6]. Samples were analysed in duplicate and the coefficient of variation for magnesium concentration was $4.0 \%$.

Skeletal muscle tissue was obtained from the lateral aspect of the quadriceps femoris muscle using a University College biopsy needle [10]. Superficial anaesthesia was obtained with $2 \%$ lignocaine, care being taken not to infiltrate below the fascia. Tissue samples usually weighed between 25 and $50 \mathrm{mg}$. Muscle samples were dissected free of adherent fibrous or adipose tissue, divided into two approximately equal parts and sealed into preweighed polythene envelopes. Light microscopy of the specimens showed a virtual absence of adipose tissue, hence lipid extraction was felt to be unnecessary. The subsequent analysis was similar to that of leucocytes and erythrocytes.
The proportion of extracellular fluid in the muscle biopsy specimen was not measured because of the relatively high concentration of intracellular compared with extracellular fluid $\mathrm{Mg}$ and the inadequacy of present techniques for measuring the extracellular fluid space [6].

\section{Results}

The findings for leucocytes and erythrocytes are summarised in Table 1 . Values are given as mean \pm standard error of mean (SEM). The significance of difference between means was assessed by Student's $\mathrm{t}$ test. Comparing diabetic patients with healthy subjects there was no significant difference in leucocyte or erythrocyte magnesium expressed as $\mathrm{mmol} / \mathrm{kg}$ dry cell solids despite a highly significant difference in the mean plasma magnesium values. A small but significant increase in erythrocyte water associated with a reduction in erythrocyte magnesium, sodium and 
Table 2. Results of plasma and skeletal muscle analyses in diabetic and healthy subjects

\begin{tabular}{|c|c|c|c|c|c|c|c|c|}
\hline & & \multicolumn{4}{|l|}{ Plasma } & \multicolumn{3}{|c|}{ Skeletal muscle } \\
\hline & & $\mathrm{Mg}$ & $\mathrm{Na}$ & $\mathrm{K}$ & \multirow{2}{*}{$\begin{array}{l}\text { Albumin } \\
(\mathrm{g} / \mathrm{l})\end{array}$} & $\mathrm{Mg}$ & $\mathrm{Na}$ & $\mathrm{K}$ \\
\hline & & \multicolumn{3}{|c|}{$(\mathrm{mmol} / \mathrm{l})$} & & \multicolumn{3}{|c|}{ (mmol/kg dry tissue) } \\
\hline Diabetic & Mean & 0.74 & 139 & 4.4 & 39.6 & 40.7 & 88.0 & 423 \\
\hline \multirow{2}{*}{$\begin{array}{l}\text { subjects } \\
n=10\end{array}$} & SEM & 0.01 & 1 & 0.1 & 0.8 & 0.9 & 3.8 & 9 \\
\hline & $n$ & 16 & 12 & 12 & 11 & 16 & 16 & 16 \\
\hline Healthy & Mean & 0.85 & 141 & 4.2 & 39.8 & 43.0 & 84.2 & 433 \\
\hline \multirow[t]{2}{*}{ subjects } & SEM & 0.02 & 1 & 0.1 & 1.2 & 0.7 & 3.1 & 5 \\
\hline & $p^{\text {a }}$ & $<0.001$ & NS & NS & NS & NS & NS & NS \\
\hline
\end{tabular}

a The significance of difference between the means was assessed by Student's $t$ test.

$n=$ number of subjects or patients

potassium was found when results were expressed as $\mathrm{mmol} / \mathrm{l}$ erythrocyte water. These differences disappeared when results were expressed in terms of dry cell weight.

The findings of the second study are shown in Table 2 . The biopsy results for the healthy subjects which were taken either under general anaesthesia or local anaesthesia have been combined, since no differences in the muscle electrolyte values were noted. There were no significant differences in muscle magnesium or potassium content between diabetic subjects and healthy subjects, despite a significant reduction in plasma magnesium concentration. There was no significant difference in mean plasma albumin between the two groups in the second study. Plasma albumin levels were measured in seven diabetic patients in the first study and did not differ significantly from normal. No significant correlation was found between plasma albumin and plasma magnesium.

\section{Discussion}

We found that the magnesium content of erythrocytes, leucocytes and skeletal muscle was normal despite hypomagnesaemia in insulin dependent diabetic patients.

Previous workers have also found that the correlation between plasma and muscle magnesium values in disease states is poor [2,9]. Thus a normal plasma magnesium concentration has been associated with a reduction in muscle magnesium content in subjects with diarrhoea [14] and after prolonged fasting [8]. There are no previous reports of skeletal muscle magnesium content in human diabetes but un- changed values were found in alloxan induced diabetes in rabbits [1].

The leucocyte results are in accord with the findings of others [18]. However, there are no studies comparing leucocyte magnesium content with another index of magnesium status, other than erythrocytes. Following jejuno-ileal bypass surgery for obesity, severe hypomagnesaemia is a common occurrence, and in this situation leucocyte and erythrocyte magnesium levels also remain normal [13].

The status of erythrocyte magnesium as an index of tissue stores is also uncertain. Results in diabetes have not revealed differences between patients and control subjects $[12,17,18]$ in agreement with the findings of the present study. We found there was a small but significant decrease in erythrocyte magnesium concentration in the diabetic patients compared with the healthy subjects, presumably related to the small increase in erythrocyte water content, but this difference vanished when the magnesium was expressed in terms of dry cell solids.

By contrast with the soft tissue studies a significant decrease has been found in the trabecular bone $\mathrm{Mg}$ content of iliac crest biopsies from insulin dependent patients compared with non-diabetic subjects [7]. Bone magnesium has been shown to correlate well with serum magnesium in patients with the hypermagnesaemia of chronic renal failure [2,3], but its relationship with hypomagnesaemia is less well defined. Nevertheless it has been suggested that bone and extracellular fluid magnesium are the major pools increased during magnesium excess and decreased during magnesium depletion $[2,3]$.

The significance of the hypomagnesaemia in diabetes, and its relationship to total body magnesium and soft tissue stores therefore remains 
uncertain. It has been proposed that hypomagnesaemia might be a risk factor in the development of diabetic retinopathy [16], and a case for dietary magnesium supplements was tentatively put forward as a possible means of reducing vascular complications of diabetes [4]. While it still remains a possibility that long term hypomagnesaemia might exert a deleterious effect on vascular disease in diabetes, our findings suggest that hypomagnesaemia is not associated with depletion in the soft tissue content of this cation.

Acknowledgements. We thank Professor J. A. Owen for help during the preparation of this manuscript.

\section{References}

1. Aikawa JK (1960) Effect of alloxan induced diabetes on magnesium metabolism in rabbits. Am J Physiol 199: 1084-1086

2. Alfrey AC, Miller NL, Butkus D (1974) Evaluation of body magnesium stores. J Lab Clin Med 84: 153-162

3. Alfrey AC, Miller NL (1973) Bone magnesium pools in uraemia. J Clin Invest 52: 3019-3027

4. Anonymous (1979) Hypomagnesaemia and diabetic retinopathy. Lancet 1: 762

5. Baron DN, Ahmed SA (1969) Intracellular concentrations of water and of the principal electrolytes determined by analysis of isolated human leucocytes. Clin Sci 37: 205-219

6. Baron DN, Levin GE (1978) Intracellular chemical pathology. In: Alberti KGMM (ed) Recent advances in clinical biochemistry, vol 1. Churchill Livingstone, Edinburgh London New York, pp 153-174

7. De Leeuw I, Vertommen J, Abs R (1978) The magnesium content of the trabecular bone in diabetic subjects. Biomedicine 29: 16-17

8. Drenick EJ, Hunt IF, Swendseid ME (1969) Magnesium depletion during prolonged fasting of obese males. J Clin Endocrinol 29: 1341-1348

9. Dunn MJ, Walser M (1966) Magnesium depletion in normal man. Metabolism 15: 884-895

10. Edwards RHT, Yound A, Wiles C (1980) Needle biopsy of skeletal muscle in the diagnosis of myopathy and the clinical study of muscle function and repair. N Engl J Med 302: 261-271
11. Jackson CE, Meier DW (1968) Routine serum magnesium analysis: correlation with clinical state in 5,100 patients. Ann Int Med 69: 743-748

12. Jain AP, Gupta NN, Kumar A (1976) Some metabolic facets of magnesium in diabetes mellitus. $\mathbf{J}$ Assoc Physicians India 24: $827-831$

13. Levin GE, Mather HM, Gazet JC, Pilkington TRE (1979) Leucocyte and erythrocyte magnesium levels after jejuno-ileal by pass surgery. Clin Chim Acta 92: 469-475

14. Lim P, Jacob E (1972) Tissue magnesium level in chronic diarrhoea. J Lab Clin Med 80: 313-321

15. Mather HM, Nisbet JA, Burton GH, Poston GJ, Bland JM, Bailey PA, Pilkington TRE (1979) Hypomagnesaemia in diabetes. Clin Chim Acta 95: 235-242

16. McNair P, Christiansen C, Madsbad S, Lauritzen E, Faber O, Binder C, Transbøl I (1978) Hypomagnesaemia, a risk factor in diabetic retinopathy. Diabetes 27: 1075-1077

17. Milewicz A, Stepien-Dobrowlska M, Szklarz E, Glebowska $H$, Gladysz A, Czarnowska J (1976) Behaviour of the magnesium level in the serum, whole blood and erythrocytes in juvenile diabetes. Wiadomosci Lakarskie 29: 599-601

18. Rosner F, Gorfien PC (1970) Zinc and magnesium levels in diabetes. J Am Med Assoc 211: 2156

19. Seelig MS, Heggtveit HA (1974) Magnesium interrelationships in ischaemic heart disease: a review. Am J Clin Nutr 27: $59-79$

20. Stutzman FL, Amatuzio DS (1953) Blood serum magnesium in portal cirrhosis and diabetes mellitus. J Lab Clin Med 41: 215-219

21. Walser M (1967) Magnesium metabolism. Ergebnisse der Physiologie Biologischen Chemie und Experimentellen Pharmakologie. 59: 185-296

22. Welch SG, Boucher BJ (1978) A rapid micro-scale method for the measurement of haemoglobin $A_{1(a+b+c)}$. Diabetologia 14: 209-211

Received: 9 September 1980

and in revised form: 29 December 1980

Dr. G. E. Levin

Department of Chemical Pathology

St. George's Hospital Medical School

Cranmer Terrace

London SW17 ORE, UK 